\title{
A NEGLECTED SOCIALIST.
}

The revolutionary year 1848 , contrary to what has been generally supposed, is the end of a distinct period of socialism, rather than the beginning of all socialistic movements in Germany. In this period lie the sources of that social political movement which at the present moment controls the legislation of the German Empire. It is as great a mistake to begin German socialism with the Communistic Manifesto of Karl Marx and Friedrich Engels as to begin the history of the American Revolution with the Declaration of Independence; and yet the former has been done by nearly all writers on the subject of socialism. Professor Adler, of the University of Basle, is almost the only writer who has done justice to the neglected period before $184^{*}$.* If the period itself has been neglected, much more have some of the most active spirits who contributed to its importance. It is with a neglected socialist of this neglected period that this paper deals.

We find ourselves in the midst of the troublous times between the July revolution of $183^{\circ}$ and the March revolution of 1848 , between the two capital cities where the life and thought of two great European nations focus. The great French revolution and its immediate effects had become history. Its sacrificial fires had gone out in the temple of Vesta, but sparks were glowing still on household hearths before the gods of Liberty, Equality and Fraternity. Napoleon's dramatic career had closed, but its influence was still mighty among the reconstructed states of Germany. A new generation had sprung up and a new code of ideas had been formulated. In France, constitution-mongers had given way to social reformers; in Germany, advocates of

* "Die Geschichte der ersten sozialpolitischen Arbeiterbezegung in Deutschland." B:eslau, $19 S_{5}$, coutains an excellent bibliography.

[7 18$]$ 
republic and unity seized the opportunity for political agitation. In France, new social theories were being discussed and social utopias invented; in Germany, political emancipation from feudal conditions was the one united aim of the discontented classes. In both countries secret clubs and unions were formed for the propagation of the new ideas. While the revolution of 1830 added to the list of liberties enjoyed by the French people, it caused the German people on the other hand to lose even the meagre liberties which they had. The harsh measures adopted by the German princes not only against conspiracies but against all liberalizing influences-especially the press-had the effect of strengthening socialism in France, and changed in the end the entire character of political agitation in Germany. The Frankforter Attentats (April 3, 1833), and the Vienna convocation led to the founding of the first unions of German refugees on foreign soil. The "German Society of the Proscribed" (Deutscher Bund der Geächteten) in Paris, and "The Young Germany" (Das junge Deutschland) in Switzerland, had the same aim: "the freeing of Germany from the yoke of dishonorable servitude, and the establishment of a condition of affairs which as far as man is able to foresee will prevent a relapse into thralldom." The new department of ideas which they found in the foreign land, they seized with the same energy with which they had entered into politics at home. As Hildebrand says, $*$ they had learned to know the unsusceptibility of the masses in Germany for their political dreams and had begun to despair of bettering the state of life at home. The wants and the shadowside of other lands impressed them. They saw the sorrows of Ireland over against English land and money aristocracy; the police centralization of France, the Jesuit endeavors of republican Switzerland. All these experiences made their patriotic hopes and ideas cosmopolitan, and they declared war on the social foundations of society.

* "Die Nationalökonomie der Gegenwart und Zukunft," Frankfort, a. M., 1848. 
By degrees the Paris union came to be composed almost entirely of laborers. The socialistic and utopian schemes of Babeuf and Fourier were eagerly read and studied. The French Republicans alarmed at the socialistic revolutionary tendency which was setting in, were moving toward the right, leaving the remnant of the "Mountain" to join itself with the proletariat. Plots and conspiracies became more and more frequent until at length the state was provoked to take summary means for their suppression, which naturally had the effect of making the unions more secret. In 1837 the "Society of Equals"-the real representation of Babeufism-had developed into the "Society of the Seasons" (Société des Saisons) with Blanqui, Bernard and Barbès at its head. Its aim was social, no longer political. Buonarroti had sometime since returned from Switzerland, whither he had been forced to flee, and had published his "History of the Conspiracy of the Equals." Babeufism, in consequence, was again rife in France. Saint Simonism as interpreted by Enfantin and Bazard had run its course, but the " new Christianity," as Lamennais presented it in his "Words of a Believer" (Les Paroles d'un Croyant), exercised an unexpected influence on the German political immigrants. Fourier, who during his life found no encouragement for the introduction of his social scheme of association, by his death in 1837 caused the tide of socialistic thought to flow in channels which he had in theory marked out. His theories, through the works of Considerant, Pellarin, and Chevalier, were brought into the daily life of the proletariat. In 1839 , Cabet returned to France from his exile in England inspired with Owenism, which he transplanted on French soil with his own originality. His "Voyage en Icarie" appeared in 1840 . This same year Proudhon published his greatest work "What is Property?" the effect of which was to double the discontent of the proletariat, and to convert no less a mind than Karl Marx to socialism. Many writers and agitators less known to literature were [720] 
making propaganda and organizing ciubs for the discussion of these great socialistic theories. The German laborers in Paris were reached through such men as Dr. Ewerbeck, Dr. Schuster, and Dr. Mäurer; men educated at the German universities, and well acquainted with the philosophies of Kant, of Fichte, and of Hegel. They had gone to France with their minds filled with abstract, political views, there intending to make propaganda for the "Republic of Germany;" but in a short time, owing to a force of circumstances and the irresistible influences of their socialistic environment, from political visionaries in the foreign land became spreaders and leaders of social theories.

It was with similar ideas, that the subject of our sketch, William Weitling, a proietarian of the proletariat, came into this tropical-socialistic atmosphere in the French capital and lived there for three years. He, too, experienced the same changes in his ideas and purposes. From the schooling he received in Paris he became an important socialistic agitator and the most prominent character, as we shall see, in the history of German socialism before I 848 .

His life before he went to Paris was a preparation and in part, at least, an index of that which followed. Born in I 808, in Magdeburg, a city celebrated in history as the hotbed of liberalism, whether in trade, religion or in politics; in an environment where speech and press were the freest of any in Germany, he knew poverty by experience and acquired by inheritance a hostile spirit toward all masters. He attended school in Magdeburg, and meanwhile served his apprenticeship to a tailor. His keen observation and warm sympathies for those who were similarly situated, made the consciousness of the existing social and economic relations galling. This consciousness became the unselfish passion of his life. He says: "If $I$ many times boil up in rage on account of the wretchedness of society, it is because I in my life have often had the opportunity of seeing misery near to, and of feeling it, in part, myself; because I as a boy was [721] 
raised in bitterest misery, so bitter, indeed, that I shudder to describe it." His life as an apprentice was unenviable. At the age of eighteen he became a journeyman. In I 828 his wanderings began and in reality did not cease until his death.

In $183^{\circ}$ he appeared in Leipzig. Already his mind was bent on reform, and he wrote radical articles describing the deplorable condition of Germany. But these efforts, as well as his verses on the movement for freedom in Saxony were refused by the Leipziger Tageblatt, to whom he offered them. Doubtless this rebuff inspired him to write that Miltonic plea for press freedom which is one of the characteristic features in his social system. In 1835 we find him a gardener in Vienna. His stay here was short, being obliged to leave, it is said, in order to avoid the rage of a prince of Hapsburg who had observed a love relation springing up between Weitling and a young woman whom the prince admired. From Vienna he went to Paris, remaining there but a few months, though long enough to feel the attractions of that city for his restless spirit. After a brief visit to Germany he decided to establish himself permanently in France. Weitling arrived in Paris in September, 1837. Not long after his arrival he became a member of the "Society of the Just" (Bund der Gerechten), which had been formed the year previous by a bolt on the part of some of the more democratic members from the Bund der Geächteten. They adopted the statutes of the latter, with but two points of diference, touching administration, namely, the secret superior officers were replaced by a standing committee called the Volkshalle; and the principle of absolute obedience was replaced by a more democratic system of regulations.

Inasmuch as this Bund forms the pattern of all the numerous organizations founded by Weitling during his career of agitation, it will be well to give a few of the details concerning it. At the head stood the Volkshalle-as a committee of administration. A strict moral life was enjoined upon each member. Whenever a member removed to another 
place or country he was expected there to establish a branch organization, make propaganda, disseminate socialistic literature, and to keep in constant correspondence with the Paris Bund. The majority of the members were laborers, a few were litterateurs. Besides Germans, the Bund comprised Swiss, Hungarians, and Scandinavians; but the language spoken was German. Public questions and social problems were discussed. Socialistic and revolutionary writings were read in the society, and also written and published by the members. Of all the socialistic systems, Cabet's found the largest number of adherents, doubtless owing to Ewerbeck who was at the same time the translator of the "Icaria" into German and also a member of the Volkshalle. The Bund stood in closest relations with the other socialistic and revolutionary societies and clubs both in and out of France. Emissaries were sent to Germany with tracts, but succeeded in gaining a foothold only in Hamburg. Political propaganda was entirely forgotten in the enthusiasm for the introduction of a socialistic state.

Weitling became a prominent member and soon took the lead as an agitator. He qualified himself also in a still more distinguished way. The year following his advent in the Bund he published "Mankind as it is and as it should be" (Die Menschheit, wie sie ist und wie sie sein sollte, 1838), the work of an eclectic, socialistic, revolutionary spirit. It builds the framework of his later published system. The first edition (2000 copies) was printed in Paris on a secret press, the work being done and the entire expense borne by the members of the Bund. Before two years had passed it had been translated into Hungarian, and had been spread over Switzerland, Germany, France, and Scandinavia. The practical side of his social philosophy showed itself in his establishing a communal eating house for his fellow laborers. This principle he attempted to carry out wherever he worked, but its success was nowhere more marked than in Paris. 
The Bund der Gerechten desiring to spread their socialistic ideas among the German laborers in Switzerland sent Weitling thither in the summer of 1840 to reconnoiter. He found the conditions most favorable. The society, Das junge Deutschland, was in a languishing condition owing to the banishment of its former leaders, and the strict police surveillance in French Switzerland. In 1841, he moved to Geneva, and thus began his career as an independent socialistic agitator. He joined a "Laborers' Educational Club" (Arbeiterbildungsverein), in order to gain a foothold for communism. But failing to win the society to his views, he withdrew and organized a Swiss branch of the Bund der Gerechten. He won Becker, a leader in the Junge Deutschland, over to communism. Simon Schmid, also a member of the Paris Bund, concerning whom Seiler wrote that "this tanner had more administrative genius in his little finger than the German ministers in all their skulls together," assisted Weitling in his plans of organization. The canton Waadt was most favorable as a base of secret operations, and from these communistic labor unions were founded in Geneva, Lausanne and around the shores of the lake. The Bund gradually spread itself over all northern Switzerland. Its open forms consisted of "educational clubs," "singing clubs," and " communal-dining associations," by means of which the propaganda spread rapidly.

Weitling further adopted the French tactics by starting a monthly organ for his agitation. In the latter part of 1841 "The Cry for Help of the German Youth" (Der Hilferuf der deutschen Jugend) appeared; its tone was moderate; its motto shows its purpose and spirit- "Against the interest of the few in so far as it works injury to the interest of all; and for the interest of all without excluding a single individual." His plans for the paper met with utter disappointment. He intended to use the profits for the founding of libraries, assemblyrooms and communistic colonies. All this failed of realization, and the paper ceased with the 
fourth number. More than all, the dining associations on which Weitling laid so much stress as a means for propaganda were badly managed. In one the treasurer escaped with the funds; in another a similar crime was prevented only because of a large deficit.

But Weitling was not discouraged. To one who makes the salvation of society his religion, such drawbacks are only incentives to larger effort. In January, I 842, he went to Vevey, where already one of his laborer unions had been established. Here he started another paper, "The Young Generation" (Die junge Generation), which made more propaganda by being confiscated on the French border than by its harmless editorials. The cantonal authorities set a watch upon him. He, meanwhile, was busy with the writing of his system, which in December secretly appeared under the title: "Guarantees of Harmony and Freedom" (Garantien der Harmonie und Freiheit). In this book he presents his social system in a clear and complete form. At this time his reputation as a thinker, socialist and agitator reached the zenith. Seiler mentions him along with Constant, Cabet and Proudhon as the fourth great evangelist of the new era.* Societies doubled in number and membership rapidly increased, so that at the beginning of the year 1843 Weitling counted with pride thirteen German and four French unions, with about 1300 members in all-the result of two years of persistent agitation. During the year 1842 he came to know Dr. Julius Froebel, a professor in the new university of Zurich, who advised him to come to Zurich because the clouds of opposition were thickening about him in the western cantons. He transferred the publication of Die junge Generation to Langenthal, in canton Bern, where it could be more cheaply and safely done; but in May, I843, he decided to move to Zurich as the Paris Bund advised him to do. He remained always in active correspondence with all the Bunds and their protégés, the labor unions. This was,

" "Die Geheimen deutschen Verbindungen in der Schwciz seit r833." Basle, 1847. 
in fact, rigidiy required in the oath taken to the Bund. When it is remembered that the whole movement was for the most part secret, it challenges wonder at the perfection of its organization.

In Zurich Weitling came in contact with two different classes: one an educated class, composed of students, writers and political refugees from Germany, who were confirmed in Hegelian philosophy, which had been playing an important rôle at the universities of Giessen and Göttingen and on the Rhine; the other a class of criminals, anarchists and atheistic communists, the more recent installment of foreigners in German Switzerland. To the former belong Dr. Froebel and Moses Hess; to the latter Michel Bakounine and William Marr, who popularized Feuerbach's philosophy among the German laborers. Neither class had influence enough to make him change his convictions, and he in the end succeeded in inclining many of them to his way of thinking. Even Bakounine, according to Adler, appears to have been won over to communism.* But the influence in this case was perhaps reciprocal and only temporary; so that the wish expressed by Weitling's Paris correspondent (Dr. Ewerbeck) that he might "form a close union and sincere intimacy with Froebel and Bakounine, which would be useful to him and to the cause," failed to be fully realized. Froebel's doubtful conversion is shown by the following from a letter to Becker (March 5, 1843): “. . . Say to Weitling that I do not know how far I can agree with him concerning the various ideas in the communistic movement, but that meanwhile my heart is with it. I divide men into egoists and communists-so consider that I belong to the latter."

Both classes hindered rather than helped Weitling's cause. More than all, the German socialism which had recently been brought to Switzerland was atheistic; while his was the French utopian socialism revised by himself with a large infusion of the religious spirit of $L_{\text {amennais. The numerous }}$

" "Iwan Golowin : Meine Bezichungen zu Herzen und Bakunin," 1880. Fage 43. [726] 
clubs that sprang up, and the utter lack of harmony of any kind anong them, checked the growth of the Bunde der Gerechten.

Weitling's next book, and in many respects his greatest, "The Gospel of the Poor Sinners" (Das Evangelium eines armen Sünders), appeared in May, 1845 . The work shows his deep religious nature and the extreme to which he went to harmonize his communistic principles with the teachings of Christianity. Communism had become a social theology, as William Marr said. Weitling turns to the Bible to establish his own theories: "The premise of Voltaire and others was that religion must be destroyed in order to rescue mankind; but Lamennais, and before him many Christian reformers, as Thomas Münzer and others, showed that all democratic ideas are the outflow of Christianity. Religion must, then, not be destroyed but used for the rescuing of mankind. . . . Christ is a prophet of freedom; His theories are the theories of freedom and love." He further interprets the New Testament as the pure gospel of communism, and Christ as the arch-enemy of property, and the founder of a communistic society. He shows clearly yet unconsciously the difference between his own views and those of the young Hegelian communists in Zurich.

Two years before Weitling's career in Switzerland was brought to a sudden close, a stirring prospectus of the "Evangelium" which he had circulated fell into the hands of the church authorities who took the matter to the state. The cantonal authorities had him seized (June 9) and imprisoned pending an investigation, and his lodgings searched. They found the manuscript of the "Evangelium," and a mass of correspondence giving almost a complete history of the communistic agitation in Switzerland. A committee of five was appointed to investigate the whole subject of the status of communism. After some months the committee made its report through its chairman, Dr. Bluntschli.* The report

* "Die Kommunisten in der Schweiz, nach den bei Weilling vorgefundenen Papieren," Zurich, 1843 . 
recommended that the state should not only crush the movement by punishing Weitling, but should adopt measures to fortify itself against the further development of such tendencies. Weitling was brought before the criminal court of Zurich and charged with blasphemy, with attacking the right of property and with founding unions of communists. The latter points he did not deny. He was sentenced to four months' imprisonment and lifelong banishment from Switzerland. Later he obtained, through his counsel, an appeal to the higher court, and his sentence was changed to six months' imprisonment and five years' banishment. This was in December, 1843 . An eventful year for German socialism had closed. Marx had had a similar experience with press propaganda in Cologne. The Rheinische Zeitung had been suppressed and Marx was in Paris publishing his "Deutsch-französische Jahrbücher." Dr. Froebel-Weitling's friend-had barely escaped a similar fate. His paper, the "Swiss Republicans" (Schweizerischen Republicaners), in consequence of the loss of subscribers ceased. Communism in Switzerland began to wane.

Weitling's career from this point on is somewhat varied. In May, I 844, he was passed across the border and was much against his will handed over to the Baden police, who delivered him up to Prussia. He was brought to Magdeburg and held as a refugee from military service, but being found to be unqualified he was released on condition that he leave Prussia. He went to Hamburg and found employment in the printing house of Hoffmann \& Campe. At this time he published his "Prison Poetry" (Kerkerpoesien), verses conspicuous for their warlike nature but of no special merit. In Hamburg he met the poet Heine who was at this time inspired with socialistic ideas. In August Weitling went to London where he was hailed as a martyr. He spoke at a meeting on the twenty-second of September, at which the communists of many lands were present primarily for the purpose of greeting him. He closed his 
speech with the toast-" To young Europe: may the democrats of all nations, casting away all jealousy and national antipathy of the past, unite in a brotherly phalanx for the destruction of tyranny and for the universal triumph of equality." In 1846 the Rheinische Jahrbücher speaking of this meeting said: "The proletariat of all nations begin under the banner of communistic democracy actually to fraternize." Professor Adler considers this meeting the first in which the socialists of various lands came together in common and emphasized the cosmopolitan principles of socialism, and says that it "led to the founding of the International." At least it may be said it was a meeting of more than ordinary historical significance.

Weitling left London and went to Brussels, where he met Karl Marx and Friedrich Engels who had fled to Belgium, Paris having become too warm on account of Guizot's policy. Brussels like London was a rendezvous for refugee socialists. They formed an association for discussion and instruction in matters touching their cause. At an evening session of socialists March 30, 184.6, Marx, Eingels, Weitling and other leaders were present. The question of the evening was: "How is it best to make propaganda in Germany ?" Marx and Engels seemed to favor conciliatory measures as being most practicable; Weitling, with Seiler his co-worker, opposed any halfway methods of expediency. He was uncompromisingly communistic, though believing in revolution only as a last resort. Regarding the discussion Weitling, in a letter to Hess (March 31, 1846), says: "Marx and Engels discussed the point violently against me. . . . I became enraged but Marx surpassed me; at last everything was in an uproar. I said: 'our discussion goes no further than that he who has the money can write what he will.' . . . I see in Marx nothing else than a good encyclopædia but no genius. Rich people made him an editor-voila tout. . . . I laid my system of labor aside when I found on all sides voices raised against it." In this letter he shows his true [729] 
nature. He advocates press freedom absolutely, not a freedom which depends on the payment of money, because if the press is governed by the money principle where is the chance for the poor man to be heard? Perhaps we can find a suggestion of truth in Weitling's standpoint. At any rate he was more consistent than Marx though certainly not as tactful and diplomatic.

In December, I 847, he went to America. Almost immediately on his arrival in New York he founded a new society which he called the "Union for Deliverance" (Befreiungsbund), in nature much the same as the Bund der Gerechten. Hearing of the upheavals in the fatherland he decided to attempt once more to make propaganda on native soil. The famous March revolution was passed when he arrived in Berlin, but uprisings were still occurring in some of the States especially in Silesia and the Palatinate. In July he started a weekly paper-Der Urwähler. It appeared only five times and then ceased from lack of subscribers. The Berlin proletariat were not yet ready for his system. They had only reached the crisis in 1848 which the French passed through in 1789 . Weitling, it is needless to say, was closely watched by the police, and in November was ordered to leave Berlin. He went again to Hamburg and there brought out a new edition of his "Garantien." In this edition his system remains unchanged. He adds, however, his positive theory of propaganda in two additional chapters: "Propaganda of the Befreiungsbund," and " Necessary Rules in the Next Social Revolution." This time the Hamburg police were on his track and he was forced to flee.

After a short stay in England he returned to America in August, 1849. In New York City he established a "Laborers' Union" whose aim was to found and sustain a communistic colony-"Communia"-in Wisconsin, whither many German immigrants were flocking. At the same time he published a paper-Republik der Arbeiter. His Wisconsin "Communia" was short-lived, meeting in 1853 the fate 
of Cabet's communal scheme in Nauvoo, Ill. Differences arose concerning the title to the land and the colony was dissolved. The "mine" and "thine" distinction on which Weitling builds his theory of the historical development of private property was too strong for the counter theory of communal property, and he found himself defeated in his plans. His newspaper also perished and he was for a brief while pecuniarily embarrassed. He soon found employment, however, as a clerk in the immigrant office at Castle Garden. His spare moments were devoted to study and invention. He took no more part in labor or socialistic agitation. When Marx's "International" established a branch in New York, Weitling did not join it, although he gave it his hearty endorsement and the benefit of his advice whenever consulted. On January 22, I871, the occasion of a brotherhood fête of German, French and English sections of the International, he was present and spoke. Three days later he died, leaving a wife and a large family of children.

So closes the life of the most prominent socialist agitator which Germany produced prior to 1848 , and when all the facts are known and rightly judged, perhaps the greatest agitator, with the single exception of Lassalle. Even Lassalle owes something to Weitling, for the agitation which began at Leipzig on that eventful twenty-third of May, 1863 , was recruited from, and heartily supported by, the followers of William Weitling.

It now remains for us to speak more in detail of Weitling's socialistic theories. We will first consider briefly his criticisms of society, and then pass to an explanation of his social state.

Weitling's most important book, "Garantien der Harmonie und Freiheit," gets its title from Fourier, with whose system of harmonies he became familiar while in Paris. He bases his socialism ever on moral grounds. Equality with him is an absolute and indisputable demand. The happiness of man is the aim of society. That man is happy who is 
contented, and he alone can be contented who can have everything that every man has. He founds his plan of reorganization of society, as did Saint Simonand Fourier, on the analysis of the nature of man. Human desires are the groundwork, as with Fourier the "passions." He divides the desires into three chief classes: (I) The desire to acquire; (2) the desire to enjoy; (3) the desire to know. "All are common to man and spring one from another, for man cannot enjoy that which he does not already have, and he cannot have without knowing where and how it is to be obtained. So that the desire of knowing is the chief motive power of the social organism by which all the others are produced." The means by which these desires are satisfied he calls the capabilities (Fähigkeiten), and the application of these capabilities is the mechanical and intellectual labor of man. The capabilities are the natural boundaries of desires; but in the satisfaction of desires new incentives are ever awakened. The desires stir up the capabilities, these the activity; the fruits of activity become enjoyments and these awaken in turn new desires. Here we have the natural law of human progress. For the satisfaction of the advancing desires man must have society in which the labors and enjoyments can be exchanged one for the other. The best organization of society is that in which that method of exchange of individual activities comes into use that least disturbs this natural law of progress; so that neither the satisfaction of desires lessens the capabilities nor the desires and capabilities of the one are held down for the advantage of the other, or are awakened and nourished to the disadvantage of others. The task of all social organization is the guarantee of freedom and harmony of all individual desires and capabilities.

As the desires have a threefold classification, so have the capabilities. Production being the capability corresponding to the first desire; consumption the second, and administration the third. Thus far only the desires of acquisition and 
enjoyment have ruled, and knowledge (Wissen) has had to bow itself under the rule of its sensuous companions. Hence, vice and crime, which are nothing else than sicknesses of the social body, have arisen out of the disharmonious organization of society. This lack of harmony is due to the principle of private property on which our present society is constructed. Private property is an historical category arising out of the principle of appropriation and the "mine" and "thine" distinctions, first as regards animals and then the land. So long as there was a superfluity of land " this law was entirely fitting for the time," but to-day the land remains just the same in quantity, while the human species has a thousandfold increased; so that there is no more land but what some lord owns, while the vast proportion of the people are landless. Here is the cause of all the evil, all the want, all the misery.

Out of private property arose the principle of inheritance, which is likened to the larvæ in the fruit. They eat up the fruit and produce nothing except eggs which insure the continuance of this destruction. When inheritance becomes general among a people they become a nation and the "mine" and "thine" principle passes over into international controversies. Thus wars arise and from wars comes slavery. But this is only the historical slavery of the person.

Money, also the result of private property, and created to facilitate exchanges of labor products, has through its misuse created a modern slavery a hundredfold more galling than either the slavery of ancient times or that of the Middle Ages. Under the latter form the lord had an interest in the slave. He took care that he did not work too hard, he nourished him when sick and provided for him in old age. From this interest and care, money has freed the labor lord. He can use up the young powers of the laborer and when they are used up, he can take other laborers into his service. Thus money has freed everyone from the care of the other and placed it upon himself; it has restricted love and increased avarice. On the 
one side it has increased the possibility of riches and power; on the other the possibility of poverty and starvation. Finally money has made the heaping up of capital possible and has thereby created the mal-relation between capital and labor, for money is an equivalent of product. Product is the result of labor. Money is therefore nothing else than coined or stored-up labor. The laborer was himself not capable of such a storing up, for the profit of his labor for the most part covered only his needs. The storing up, therefore, originated first from this cause that some one let others work for him, and sold the products of labor at a higher price than he had received them at from the laborer. So profits on profits, embodied in money, were created entirely by the hands of the laborer, but illegitimately taken from him by those who sold the product. And so arose capital and the class of capitalists who rule the laborers. Capital is therefore originally the property of the laborers. Besides capital begets in itself no interest, except through human labor. The capitalist has therefore his riches not alone from the laborer, but increases them daily through the laborer who produces for him the interest. The greater his capital the wider in extent and the more pressing becomes his rule over the laborers and the faster his riches accumulate, especially when anarchy-the right of the strongest (das Faustrecht des Geldes) - is exalted into a law. In fine the money system hinders and postpones every calculable progress for the good of all, because the money man supports only that which offers to him personal advantage. In Weitling's social state money finds no place. Its functions are to be performed by the "Kommerzbuch," hereinafter described.

We now turn to consider Weitling's social state. Society demands, first of all, the granting of that place to science which is due her alone, namely, the regulating of all the desires and capabilities. The power which resides in the community must not be given to a prince or a dictator, nor to a majority vote in a republic, but it must rest upon the 
intelligence which is independent of all personal infiuences. This is the fundamental premise on which he builds his intellectual-socialistic state. At the head of the state stand the three greatest philosophers-a triumvirate-with whom rests the supreme control and administration. Under them stand a central assembly of masters, an academic council and a health council; and under these in turn the master companies, academic and health commissions respectively, and so on down to the separate work-masters, teachers and health officers. All the higher officers, with the exception of the triumvirs, are chosen by the competitive method. Each candidate produces a masterpiece and attaches a sign to it which corresponds to a similar sign in a second letter with his name. The choice is thus made without the name or person being known. The choice of the health officers is somewhat different. There the lot falls to him who can show the largest number of successful cures.

The triumvirs estimate all the physical and intellectual needs of consumption according to the statistical testimony of local under officers, and fix the quantity and time of labor for all equally. Six hours of labor are to be the average amount required per day. All material products and intellectual labor are estimated according to their value in labor hours; and the authorities fix the ratios of exchange. Kommerzbücher constitute the means for facilitating exchanges. These books are issued yearly to each individual, and contain a complete description of the possessor, his portrait, signature and history. They contain sixty leaves, one for every five days, or for 300 working days in the year. A debit and credit system is here carried on. The possessor is credited in his book with as many hours of surplus labor as he has furnished. Against this he is charged with enjoyment hours and all agreeable products which he consumes. If he does not work overtime, then he cannot enjoy anything beyond that which is common. The system amounts to this, that all receive a guarantee of support and enjoyment 
for the rendering of six hours of labor service daily; beyond this the enjoyments of each depend on the surplus of labor rendered. The unfit are the special care of the health department, and are to be removed far from the possibility of contaminating the fit. All children at six years of age join the public school army, which is to be a preparation for communistic citizenship. An elaborate system of instruction in all kinds of labor is provided which ends only at the university. Examinations take place for promotion from one grade to another and from one sphere of industry to another. Marriage remains as it is. The women enjoy the same rights and carry the same responsibilities in relation to labor and enjoyment as the men, except that lighter grades of work are reserved for them by the triumvirs.

Such is Weitling's social utopia. How the change from the present order of society to this new order is to take place is as difficult for Weitling to solve without overleaping the bounds of natural development as for all other social reformers. But more than some writers, Proudhon, for example, he has a scheme and it is his own. The very first step-one which has thus far been overlooked-is to drive the present form of industrial society to its evil consequences as soon as possible, and precisely on the Keeley cure plan introduce gradually revolutionary measures. The new order will set in automatically, as in Louis Blanc's scheme. When in a village, city, or district three-fourths of the inhabitants by vote declare for the new order and offer their possessions therefor, the rest are compelled to do so, and the new order is established. If resistance is offered, then more drastic measures are resorted to. The proletarians are to declare a provisional government, depose all existing officers, especially the police and judges, and elect new officers from their own ranks. The rich are to be disfranchised and compelled to support the poor and destitute while reconstruction is pending. The property of the state and of the church at once becomes communal. Those who choose to leave the 
country may do so, their property being confiscated. The rich who offer their means for the support of the new society are promised a pension during life; the rest, by limitations on their activity, by punishments and penalties, will be forced to succumb. If all these means fail, then "a moral must be preached which no one now dares to preach." A revolution after the order of Babeuf is the "moral."

It is not the purpose of this paper to enter into a critical analysis of Weitling's economic theories or his social system, but simply to present the facts of his career and the main features of his system, and to emphasize more strongly than has yet been done his position in the history of socialism.

Three reasons may be given for his having been overlooked: first, because of the scarcity of copies of his books, since they were confiscated and forbidden circulation in Switzerland, France and Germany, the sources of information concerning him and his work, most of which were favorable to his views, have likewise been suppressed; second, because of the purely political phase in which the revolution of 1848 appeared in Germany; and third, because of the overshadowing growth of a new scientific socialism based on English political economy and Hegelian philosophy, as represented by Karl Marlo, Karl Rodbertus and Karl Marx. The latter movement came from the schools, Weitling's came from practical experience expressed in terms of French socialistic philosophy. The former was busy with the Why, the latter suggested the How; the former had the theory, the latter the practice. Both were brought to a focus in Ferdinand Lassalle. The former produced the " thinker," the latter the "fighter." To both movements the German Social Democracy of to-day owes its origin.

Weitling's position in the history of German socialism is unique, chiefly on account of the fact that he comes from the ranks of the proletariat. From a journeyman tailor he raised himself to the front rank as a socialistic writer, and created the first socialistic movement among the German 
laboring classes. Marx recognizes his ability and importance when he says: "Concerning the educational condition or the educational ability of the German laborer in general, I am reminded of the gifted writings of Weitling, which often even surpass Proudhon, however impracticable they may be. Where could the bourgeoise-their philosophers and learned writers taken together-show a work equal to Weitling's 'Guarantees of Harmony and Freedom,' in relation to their political emancipation ! . . . it is a measureless and brilliant literary dêbut of the German laborer When one forms his conclusions of Weitling's book he must admit that the German proletariat is the theorician of the European proletariat, as the English proletariat is the economist, and the French the politician."* Fr. Engels refers to the "social-democratic tailor" as the "only German socialist who has actually done anything." $\dagger$

Weitling certainly anticipated in many ways the teachings of later socialists. He is the advocate of unqualified freedom; freedom of speech and of the press, of political and of economic freedom. His motto is: "Frei wollen wir werden wie die Vögel des Himmels." He is also a prophet of deliverance. The social revolution, he considers, must and will come in the natural order of things. "A new Messiah will also come to bring about the teachings of the first." $\mathrm{He}$ does not pretend to give the picture of the absolutely best society, but like Lycurgus' constitution, it is the most perfect according to the present knowledge and the best the people can stand. He says: "Never will an organization of society be found which is unchangeably the best for all time, because that takes for granted a standstill of the intellectual capabilities of man, a standstill of progress which is not conceivable. Progress is a law of nature; a standstill is a gradual decomposition of society. To hinder the latter

* Vorwärts, Paris, I844.

+ Deutsches Bürgerbuch, 1846 . 
and to aid the former is the concern of us all and not of a privileged caste." He here and everywhere lays stress upon the evolutionary development of the race, especially upon its intellectual side, hence the importance of the school army in his system and the education of all classes and both sexes. "Science," he says, "must cease to be a privilege; it must be studied by all. Philosophy (in the sense of knowledge) must rule." 'This he makes the foundation of his future state.

Whatever judgment the critic may pass upon Weitling's theories in particular or on his system in general, this much is certain, that he forms the bridge between French and German socialism; between the materialism of the former and the humanitarianism of the latter. He is the only German socialist that constructed a system and had the courage to carry it out. Judged by his writings, his place is by the side of Fourier and Engels; judged by his services and his agitation, Lassalle alone outranks him.

Frederick C. Clark.

Berlin. 